Elżbieta Osewska

Państwowa Wyższa Szkoła Zawodowa

w Tarnowie

\title{
Posługa katechetyczna Kościoła partykularnego
}

„Posługę katechetyczną otaczał Kościól w Polsce zawsze najwyższą troską. Stanowiła ona - zwłaszcza w ostatnich dziesiątkach lat - jedną z głównych form oddziaływania duszpasterskiego na wiernych, przede wszystkim na dzieci i młodzież. Szczególnie bogate i cenne doświadczenia katechetyczne zdobył Kościół w ostatnim półwieczu, w czasach tzw. realnego socjalizmu, przez wprowadzenie do parafii powszechnej katechizacji wszystkich grup wiekowych, zorganizowanej na wzór katechezy szkolnej. Jakkolwiek dziś stanęła przed katechetami konieczność wypracowania nowego modelu katechezy, przystosowanego do zmienionych okoliczności i uwzględniającego uwarunkowania szkolne, nie można i nie powinno zatracić się tych wypracowanych z wielkim trudem i wśród dramatycznych zmagań osiągnięć z okresu katechezy parafialnej"1. Kościół w Polsce zawsze dbał o rozwój katechezy, dostrzegając w niej możliwość pogłębionej formacji dzieci, młodzieży i dorosłych. Szczególnie w czasach panowania systemu socjalistycznego, kiedy starano się przekonać społeczeństwo, że wiara jest ich sprawą prywatną i niezwiązaną z życiem zawodowym, społecznym i narodowym. Powstało wówczas przeświadczenie, że można wierzyć w Boga, chodzić do kościoła, ale ostatecznie dostosowywać się publicznie do wymagań PZPR i żyć w innym 
wymiarze wartości. Ten dualizm postaw życiowych spowodował swoistą schizofrenię życiową, zrodził rozdźwięk między wyznawaną wiarą a życiem. W tym kontekście przywrócenie właściwego miejsca katechezie, łącznie z nauczaniem religii w szkole publicznej było i pozostaje sprawdzianem demokracji społeczeństwa. $Z$ tych między innymi powodów należy podjąć w niniejszym artykule zagadnienie posługi katechetycznej realizowanej w Kościele partykularnym. Zostanie ono przedstawione $\mathrm{z}$ uwzględnieniem zadań, które wynikają z kontekstu historyczno-społecznego katechezy w Polsce, podstawowych środowisk pedagogiczno-katechetycznych oraz wskazaniem rangi i znaczenia katechezy realizowanej w parafii.

\section{Zadania wypływające}

z kontekstu historyczno-społecznego katechezy w Polsce

Zarówno teoria, jak i praktyka pastoralno-katechetyczna rozwijały się bardzo intensywnie w XX wieku i mimo niesprzyjających warunków w okresie socjalizmu i trudności w początkowym okresie transformacji społeczno-politycznej można mówić o znaczących osiągnięciach obejmujących teorię katechetyczną, organizację samej katechezy na poziomie diecezjalnym i parafialnym oraz formację katechetów (kapłanów, osób zakonnych i świeckich). Należy pamiętać o ogromnej roli, jaką w tym względzie pełniły i nadal pełnią akademickie ośrodki kształcenia oraz diecezjalne wydziały katechetyczne. Katecheza w Polsce mimo ,żelaznej kurtyny” pozostawała w kontakcie z zagranicznymi centrami katechetycznymi i korzystała z ich osiągnięć, ale nie jako bierny odbiorca, lecz jako aktywny uczestnik podejmujący wypracowane w Europie Zachodniej nowe kierunki i tendencje katechetyczne, ale zachowujący także rodzimą tradycję i osiągnięcia katechetyczne diecezjalne wydziały katechetyczne ${ }^{2}$.

Obecnie Kościół w Polsce, dostrzegając zachodzące niezwykle dynamicznie procesy polityczne, społeczno-moralne, ekonomiczne, kulturowe, edukacyjne i religijne, potrzebuje dobrej diagnozy stanu życia społecznego, jego oceny zgodnie z założeniami nauki społecznej Kościoła, a następnie sformułowania wniosków i postulatów

2 Por. PDK 3. 
pastoralno-katechetycznych. Niniejsze badania powinny być prowadzone zarówno na poziomie całego kraju, jak i poszczególnych regionów - diecezji z uwzględnieniem ich specyfiki. Bez adekwatnej diagnozy wszelkie działania pastoralno-katechetyczne pozostaną jedynie w sferze myślenia życzeniowego i sporadycznych akcji duszpasterskich. Zazwyczaj każdy Kościól partykularny ma swoją specyfikę wyrastającą z określonych doświadczeń historyczno-społecznych, stąd inną specyfikę posiada diecezja tarnowska, krakowska czy rzeszowska, inną szczecińsko-kamieńska czy koszalińsko-kołobrzeska, jeszcze inną katowicka czy gliwicka, a zupełnie inną łódzka lub warszawska. Dlatego w każdym Kościele partykularnym potrzeba budowania katechezy z odniesieniem do mocnych lokalnych fundamentów społecznych, kulturowych i religijnych oraz z uwzględnieniem słabości i niedoskonałości danej diecezji.

Jednym z pierwszych i bardzo pilnych zadań pastoralno-katechetycznych jest także odbudowanie lub kształtowanie prawdziwej odpowiedzialności chrześcijańskiej za Kościól, pogłębione formowanie świadomości, iż żaden chrześcijanin jako część Kościoła powszechnego i partykularnego nie może biernie przyglądać się propagandzie medialnej atakującej Kościól, ale winien podejmować odpowiedzialność za siebie, bliźnich i cały Kościól. Wiara wypływająca z wolnej decyzji człowieka daje podstawy aktywności i możliwość przemiany życia, bowiem ukierunkowuje na „dojrzałość według pełni Chrystusa”, czyli nadaje sens życiu. W tej sytuacji niezbędna jest troska o mądrą formację katolików, aby potrafili coraz pełniej zrozumieć samych siebie, innych ludzi, zachodzące przemiany społeczne, polityczne, kulturowe i religijne. Należy pomagać ludziom wierzącym, by uczyli się analizować otaczającą ich rzeczywistość i kształtować myślenie i działanie zgodnie z założeniami Ewangelii ${ }^{4}$.

Kongregacja ds. Duchowieństwa, Dyrektorium ogólne o katechizacji [dalej: DOK], Poznań 1998, 56.

4 Por. J. Stala, Handlungskompetenzen des Religionslehrers und Katecheten, eine an der Vermittlung pädagogischer und katechetischer Fähigkeiten orientierte Ausbildung, ,The Person and the Challenges” 4 (2014) nr 1, s. 141-156; tenże, Katechese im Zeitalter der Postmoderne. „Grundsatzprogramm für die Katechese der Kirche in Polen“ aus dem Jahr 2010, „Bogoslovni Vestnik“ 74 (2014) nr 1, s. 107-117; tenże, Richtungsweisende Merkmale zur religiösen Erziehung und Bildung im Lehrwerk von Papst Johannes Paul II., ,,Bogoslovska Smotra“ 2014 nr 1, s. 137-148; tenże, Die Freiheit - das besondere Kennzeichen 
W odkrywaniu sensu życia i kształtowaniu mentalności chrześcijańskiej powinna pomagać katecheza, która przez tworzenie sytuacji nawrócenia zaprasza do udziału w planie zbawienia. Motywując katechizowanych, ułatwia przyjęcie łaski do naśladowania Jezusa Chrystusa i przybliża ich do komunii z Nim . Wybór pójścia za Jezusem Chrystusem, ku któremu kieruje swego odbiorcę katecheza, nie jest wynikiem jednorazowego aktu woli, lecz wymaga nieustannego wysiłku. $Z$ tego powodu każdy chrześcijanin potrzebuje wsparcia od swego Kościoła partykularnego. Dobrze przeprowadzona diagnoza pastoralna na terenie danej diecezji pomaga określić mocne i słabe strony wierzących danego Kościoła partykularnego, określić ich możliwości, ale także słabości i potrzeby. W diecezji, w której przeważają skupiska miejskie, wielość wplywów kulturowych i religijnych, gdzie procesy laicyzacyjne poczynily znaczne postępy, trzeba podjąć inne działania katechetyczno-pastoralne niż w diecezji z dominacją terenów rolniczych i zachowaną jednorodnością religijną. Silne więzi społeczno-religijne przyczyniają się do budowania wspólnoty i tworzenia mocnych zasad społecznych, moralnych, religijnych, co wpływa na kształtowanie się całego procesu katechetycznego.

\section{Podstawowe środowiska katechetyczne}

Analiza sytuacji pastoralno-katechetycznej w Polsce wskazuje, że duże znaczenie w rozwoju katechezy i poszczególnych wierzących ma także wspólpraca środowisk katechetycznych i ich w miarę jednolite odziaływanie na osobę. Procesy wychowania do wiary, podejmowane w rodzinie, są wówczas wspierane przez parafię, szkołę, grupy dziecięce i młodzieżowe, co w dużym stopniu przyczynia się do formowania dojrzałej wiary. Wprawdzie stopniowe trudności społeczne skłaniająjednostkę do weryfikacji swoich przekonań i postaw, czyniąc wiarę bardziej świadomą i żywą̧, jednak osoba pozbawiona wsparcia wspólnoty rodzinnej, religijnej czy grupy zawodowej może łatwo ulec

einer modernen Jugenderziehung, ,,The Person and the Challenges” 3 (2013) nr 2, s. 193-207.

5 Por. J. O'Shea, V. Cosstick, D. Lundy, Parish Project, London 1992, s. 2-4.

6 Por. II Sobór Watykański, dekret Apostolicam acuositatem, 4; tenże, konst. Lumen gentium, 25. 
obojętności religijnej i dostosowywać się do aktualnego przekazu medialnego. Troszcząc się o wszystkich wierzących, Kościól partykularny winien dbać o doskonalenie ich umiejętności krytycznej oceny istniejącej rzeczywistości społecznej, jej diagnozę w świetle Objawienia oraz ich zaangażowanie w życie zgodne z Ewangelią Jezusa Chrystu$\mathrm{sa}^{7}$. Nie uda się tego osiągnąć bez zaangażowania wszystkich środowisk pedagogicznych i katechetycznych. Działalność katechetyczna Kościoła odnosi się do wszystkich środowisk katechetycznych: rodziny, szkoły i parafii, dlatego konieczne jest wzajemne wspomaganie wysiłków rodziców, nauczycieli, wychowawców, duszpasterzy i katechetów parafialnych, podejmowanych w katechezie rodzinnej, na lekcjach religii w szkole i w ramach różnorodnych form katechetycznych w parafii.

Podstawowym środowiskiem wychowania do wiary, wzmocnionym łaską sakramentu małżeństwa jest zarówno w sensie chronologicznym, jak i aksjologicznym rodzina chrześcijańska ${ }^{8}$. Działania

7 Por. II Sobór Watykański, konst. Gaudium et spes [dalej: GS], 56-57; Paweł VI, adh. Evangelii nuntiandi, 20; DOK 20-21.

8 Por. II Sobór Watykański, dekl. Gravissimum educationis [dalej: GE] 3; GS 48. W Polsce od dawna intensywnie rozwijają się poszukiwania naukowe w zakresie katechezy rodzinnej. Zob. np. M. Majewski, Zainteresowanie katecheza rodzinna i próby jej interpretacji, ,Roczniki Teologiczno-Kanoniczne” 22 (1975) z. 6, s. 39-54;tenże, Całościowa interpretacja katechezy rodzinnej, [w:] tegoż, Pedagogiczno-dydaktyczne wartości katechezy rodzinnej, Kraków 1995, s. 6174; J. Tarnowski, Katecheza w rodzinie: obawy i nadzieje, „Katecheta” 25 (1981) nr 6, s. 255-258; tenże, Spotkać Boga w rodzinie, ,Katecheta” 26 (1982) nr 1, s. 101-110; J. Wilk, Próba teologicznego uzasadnienia katechumenatu rodzinnego, „Roczniki Teologiczno-Kanoniczne” 24 (1977) z. 6, s. 71-83; tenże, Wartość katechumenatu dla wychowania chrześcijańskiego, ,Roczniki Teologiczno-Kanoniczne" 30 (1983) z. 6, s. 273-283; E. Osewska, Katecheza rodzinna. Katecheza $w$ rodzinie, [w:] Stownik matżeństwa i rodziny, red. E. Ozorowski, Warszawa-Eomianki 1999, s. 186-188; Drogi katechezy rodzinnej, red. E. Osewska, J. Stala, Poznań 2002; E. Osewska, Katecheza rodzinna, [w:] Katechetyka szczegótowa, red. J. Stala, Tarnów 2003, s. 255-292; taż, Katecheza w rodzinie jako element integrujący podstawowe doświadczenia ludzkie z rzeczywistością wiary, ,Studia nad Rodziną" (1999) nr 1, s. 143-153; taż, Katecheza $w$ rodzinie - prawda i zludzenia, [w:] Komunikacja wiary w trzecim tysiacleciu, red. S. Dziekoński, Olecko 2000, s. 41-62; J. Stala, Podstawy teologiczno-antropologiczne katechezy rodzinnej, Tarnów 1998; tenże, Katecheza o matżeństwie i rodzinie $w$ Polsce po Soborze Watykańskim II. Próba oceny, Tarnów 2004; Dzisiejsze aspiracje katechezy rodzinnej. Problemy i wyzwania, red. J. Stala, Kielce 2005; Rodzina - bezcenny dar $i$ zadanie, red. J. Stala, E. Osewska, Radom 2006; J. Stala, Familienkatechese 
katechetyczne podejmowane we wspólnocie rodzinnej, oparte na silnej więzi miłości łączącej matkę i ojca, rodziców i dzieci, rodzeństwo, dziadków i wnuków sąjednocześnie realizacją misji zleconej rodzicom przez Boga i kontynuacją Jego stwórczego dzieła9. Rodzice chrześcijańscy, rodząc w miłości i dla miłości nową osobę, przyjmują na siebie zadanie umożliwienia jej życia w pełni ludzkiego i chrześcijańskiego. Miłość łącząca męża i żonę oraz członków rodziny nadaje rodzinie pierwszeństwo w procesie rozwoju i wychowania człowieka. Wychowanie religijne dziecka zaczyna się w rodzinie już od poczęcia, trwa przez okres życia prenatalnego i kolejne lata po urodzeniu. Żadna instytucja nie może podjąć funkcji wychowawczej od samego początku życia człowieka, odtworzyć miłości łączącej członków rodziny, ani tak jak ona zaspokoić różnorodnych potrzeb swoich członków ${ }^{10}$. W związku z tym działalność katechetyczna podejmowana w rodzinie, budowana w oparciu o poszanowanie ludzkiej godności, miłości, odpowiedzialności oraz łaskę sakramentów, pozostaje pierwsza, oryginalna i niezastępowalna ${ }^{11}$.

Katecheza podejmowana w rodzinie wiąże się ściśle z przekazywaniem życia ludzkiego oraz przyjęciem przez rodziców sakramentów: chrztu, pokuty i pojednania, Eucharystii, bierzmowania oraz małżeństwa. Rodzina jest wspólnotą osób, której wewnętrzną zasadą, siłą i ostatecznym celem jest miłość. Bez miłości rodzina nie może żyć, wzrastać, doskonalić się oraz podejmować zadań pedagogicznych i katechetycznych ${ }^{12}$. Miłość łącząca męża i żonę oraz

in Polen um die Jahrhundertwende. Probleme und Herausforderungen, Tarnów 2008; tenże, $W$ kierunku integralnej edukacji religijnej $w$ rodzinie. Próba refleksji nad nauczaniem Jana Pawła II w kontekście polskich uwarunkowań, Tarnów 2010; tenże, Ręce mego ojca i usta mojej matki powiedzialy mi najwięcej o Bogu. Biskupa Piotra Bednarczyka ujęcie katechezy rodzinnej, Tarnów 2011.

$9 \quad$ Por. Jan Paweł II, List do Rodzin, 16; W poszukiwaniu katechezy rodziców. Studium teoretyczno-empiryczne, red. J. Stala, E. Osewska, Tarnów 2007; J. Stala, E. Osewska, Anders erziehen in Polen. Der Erziehungs-und Bildungsbegriff im Kontext eines sich ständig verändernden Europas des XXI. Jahrhunderts, Tarnów 2009; Religious Education / Catechesis in the Family. A European Perspective, red. E. Osewska, J. Stala, Warszawa 2010.

10 Por. W. Tabaczyński, Rodzina. I. Pojęcie, [w:] Stownik matżeństwa i rodziny, dz. cyt., s. 388; J. Stala, Wychowanie dziecka do wiary $w$ rodzinie $w$ perspektywie teologicznej, ,Studia nad Rodziną” 17 (2013) nr 1 (32), s. 25-37; tenże, Richtungsweisende Merkmale..., dz. cyt., s. 137-148.

11 Por. Jan Paweł II, adh. Catechesi tredendae [dalej: CT], 68.

12 Por. Jan Paweł II, adh. Familiaris consortio [dalej: FC], 18. 
członków rodziny nadaje rodzinie pierwszeństwo w procesie rozwoju i wychowania człowieka. Rodzina chrześcijańska pozostaje pierwszym i uprzywilejowanym środowiskiem katechetycznym ${ }^{13}$, gdyż przez rodziców, opiekunów, dziadków i wszystkich innych członków rodziny jest stopniowo podejmowane wychowanie człowieka do wiary i wychowanie w wierze ${ }^{14}$. Przy czym w rodzinie, bardziej niż w innych środowiskach katechetycznych, dominuje funkcja wychowania oraz wtajemniczenia oparta na świadectwie życia chrześcijańskiego dorosłych członków rodziny ${ }^{15}$. Dlatego odpowiedzialni za katechezę w Polsce i w poszczególnych diecezjach, szczególnie $\mathrm{w}$ obliczu intensywnych ataków na rodzinę, powinni najpierw zatroszczyć się o rodzinę, jej wewnętrzną spójność, podtrzymywanie jej więzi, miłość i szacunek, wspieranie jej funkcji opiekuńczo-wychowawczej i religijnej, a dopiero na tej bazie dokonywać przekazu treści teologicznych ${ }^{16}$.

Za środowisko katechetyczne jest również uznawana szkoła, zwłaszcza szkoła katolicka. Przy czym wśród polskich katechetyków od dłuższego czasu trwa dyskusja dotycząca relacji między katechezą a nauczaniem religii w szkole. Jej uczestników można podzielić na dwie grupy: pierwsza obejmuje specjalistów, którzy uważają, iż spór jest pozorny, bowiem pytanie o charakter nauczania religii w szkole i uznanie nauczania religii za ,katechezę szkolną” jest raczej sporem dotyczącym terminologii niż praktyki. Natomiast druga grupa twierdzi, że to spór zasadniczy i należy precyzyjnie określić różnice między katechezą a nauczaniem religii w szkole. Nie wnikając w szczegóły prowadzonych sporów, należy zauważyć, że w środowisku szkolnym nie uda się w pelni realizować wszystkich funkcji katechezy ${ }^{17}$, bowiem o ile szkoła pozostaje środowiskiem przekazywania wiedzy i wychowania, w czym uczestniczy także nauczanie religii przez realizację funkcji nauczania i wychowania, o tyle duże wątpliwości budzi realizacja funkcji ewangelizacyjnej oraz inicjacyjnej ${ }^{18}$. Uznanie, że

\footnotetext{
13 Por. DOK 255.

14 Por. GE3; FC 37; DOK 255.

15 Por. DOK 226.

16 Por. Jan Paweł II, List do ludzi w podeszłym wieku (1 X 1999), 11.

17 Por. CT 18; Por. P. Tomasik, Religia $w$ dialogu z edukacja, Warszawa 2004, s. $139-260$.

18 Por. R. Murawski, K. Misiaszek, Katechizacja: szanse i trudności, „Ateneum $100 \quad$ Kapłańskie" 1993 z. 507-508, s. 233.
} 
nauczanie religii w szkole wypełni wszystkie cele, zadania i funkcje katechezy prowadzi do klęski wychowawczej, a jednocześnie przyczynia się do zniechęcenia i demotywowania zarówno nauczycieli religii, jak i uczniów. Brak oddzielenia pojęć „katecheza” i „,nauczanie religii" niesie w konsekwencji skutki praktyczne. Przede wszystkim staje się przyczyną budowania konfrontacji między szkołą a katechezą. Dodatkowo powoduje osłabianie roli szkoły jako środowiska wychowawczego. Zaś koncepcja, wedle której katecheza w szkole realizuje wszystkie jej funkcje, minimalizuje znaczenie form katechetycznych podejmowanych na terenie parafii. Jeśli podejmowane w szkole nauczanie religii realizuje wszystkie cele katechetyczne, to katecheza parafialna staje się zbyteczna. A jak w rzeczywistości szkolnej ma być realizowana inicjacja sakramentalna i spotkanie człowieka wierzącego z Bogiem w sakramentach ${ }^{19}$ ?

Podmiotem nauczania religii w szkole są zarówno szkoła, jak i Kościół ${ }^{20}$. Kiedy zatem mówi się o nauczaniu religii, względnie o katechezie, w kontekście reformy edukacyjnej, trzeba pamiętać, że Kościół nie chce wykorzystywać szkoły, ale wraz z całym systemem szkolnym pragnie służyć młodemu człowiekowi w procesie formowania jego dojrzałości osobowej i religijnej, dlatego podejmuje wybrane cele edukacyjne. Gdyby nauka religii nie realizowała celów szkoły, a szkoła była jedynie miejscem udostępniającym swoje sale dla nauczania religii, to należałoby przyjąć marksistowskie rozumienie, że religia jest zbędnym, obcym elementem w środowisku szkolnym ${ }^{21}$.

Zgodnie z Dyrektorium katechetycznym Kościola katolickiego w Polsce można przyjąć, iż nauczanie religii w szkole i katecheza uzupełniają się. ,Zarówno w katechezie, jak i w szkolnym nauczaniu religii podmiotem działającym jest Kościól. W katechezie aktualizuje się on przez parafię, w szkolnym nauczaniu religii przez fakt udzielenia nauczającym religii misji kanonicznej. W szkolnym nauczaniu religii podmiotowy charakter zachowuje, obok Kościoła, także szkoła. Szkolne nauczanie religii winno zatem wypełniać zarówno zadania postawione przez Kościól, jak i wybrane cele, wyznaczone przez szkołę. Stosunek nauczania religii wobec szkoły wyrażają

19 Por. J. Szpet, Inicjacyjna funkcja katechezy, „Horyzonty Wiary” 1996 nr 3, s. 57.

20 Por. P. Tomasik, Nauczanie religii w publicznym liceum ogólnoksztatcacym wobec założén programowych polskiej szkoly, Warszawa 1998, s. 149-154.

21 Por. M. Kozakiewicz, Nauczyciel i religia, Warszawa 1961, s. 156. 
relacje zarówno podporządkowania, jak i autonomii. Podporządkowanie oznacza przede wszystkim włączenie katechety szkolnego w zakres odpowiedzialności za realizacje planu wychowawczego i dydaktycznego szkoły. Nauczanie religii podlega rygorom, jakie stosuje się wobec innych przedmiotów w zakresie nadzoru pedagogicznego. Jednakże nauczanie religii cieszy się autonomią wobec instytucji szkoły. Wyraża się ona w fakcie, że programy nauczania i pomoce dydaktyczne nie podlegają zatwierdzeniu przez nadzór pedagogiczny, lecz winny być jedynie podane do jego wiadomości. Oznacza to, że nadzór merytoryczny nad nauczaniem religii w szkole sprawuje Kościół. To Kościół zatwierdza materiały dydaktyczne i kieruje katechetów do podjęcia pracy w szkole (misja kanoniczna), a także w ramach prac programowych określa, które cele i zadania szkoły winny być realizowane na lekcjach religii. Tak ujęta lekcja religii umożliwia współdziałanie szkoły i Kościoła, a jednocześnie szanuje wzajemną autonomię obu tych podmiotów nauki religii" 22 .

\section{Znaczenie katechezy parafialnej}

Katecheza jest $\mathrm{z}$ jednej strony jednym $\mathrm{z}$ najważniejszych zadań posługi duszpasterskiej Kościoła, zaś z drugiej jest realizowaniem przezeń niezbywalnego prawa każdego wierzącego wynikającego z przyjęcia chrztu, na mocy którego ma „prawo otrzymać od Kościoła naukę i wychowanie, które umożliwią mu dojście do życia prawdziwie chrześcijańskiego"²3. Od tego, na ile Kościół partykularny i wspólnota parafialna umożliwią funkcjonowanie katechezy, zależy rozwój ich życia wewnętrznego jako wspólnoty wierzących oraz ich działania na zewnątrz jako wspólnoty misyjnej ${ }^{24}$. Cały Kościół partykularny jest odpowiedzialny za katechezę, pozostając zarówno jej nadawcą, jak i adresatem. Jednak trzeba pamiętać, że odpowiedzialność za katechezę jest zarówno wspólna, jak i zróżnicowana ${ }^{25}$, bowiem każdy wierzący w swoim zakresie, odpowiednio do swojej

22 PDK 82.

23 CT 14.

24 Por. CT 15; PDK 119.

10225 Por. CT 16; PDK 120. 
pozycji w Kościele, podejmuje i realizuje zadania katechetyczne ${ }^{26}$. Dzięki temu, że działalność katechetyczna jest urzeczywistniana przez różne osoby pełniące odmienne funkcje w Kościele w różnych środowiskach, Kościół może głosić Ewangelię i formować wierzących w różnych miejscach ${ }^{27}$, z zachowaniem znaczenia parafii jako ważnego środowiska katechetycznego. Kościól partykularny winien dbać, by żywa, dynamiczna parafia umożliwiała realizację bogatej w treści, formy, metody i środki katechezy ${ }^{28}$ przy zachowaniu troski o formację chrześcijańską dzieci, młodzieży oraz osób dorosłych. Wydaje się, że jednak należy przywrócić katechezie parafialnej jej rangę, szczególnie w procesie przygotowania do sakramentów inicjacji chrześcijańskiej ${ }^{29}$.

„Katecheza z natury swej jest związana w sposób szczególny ze sprawowaniem sakramentów, «gdyż właśnie w sakramentach, a zwłaszcza w Eucharystii, Jezus Chrystus działa najpełniej w celu przemiany człowieka» ${ }^{30}$. Katecheza winna budzić postawy i kształtować umiejętności, warunkujące owocny udział w życiu sakramentalnym. W przypadku katechezy dorosłych formami najbardziej naturalnymi będą, poza homilią, przygotowanie do przyjęcia sakramentu małżeństwa, katecheza dla uczestniczących w sakramencie chrztu rodziców i chrzestnych, a także stała formacja katechetyczna. Gdy chodzi o katechezę dzieci i młodzieży, to katecheza winna mieć charakter ścisłle liturgiczny na wszystkich etapach edukacyjnych: dzieci młodsze przygotowuje do uczestnictwa w Eucharystii oraz w sakramencie pokuty i pojednania, dzieci starsze wprowadza w lekturę Pisma św. i do świadomego wyznania wiary, młodzież gimnazjalną przygotowuje do przyjęcia sakramentu bierzmowania, zaś młodzież ponadgimnazjalną do odczytania i wyboru drogi powołania i założenia rodziny chrześcijańskiej”31. Katecheza realizowana w parafiach musi zatroszczyć się o przygotowanie katechizowanych nie tylko do pierwszego spotkania z Jezusem

26 Por. DOK 219; CT 16; J. Stala, Katechese im Zeitalter der Postmoderne..., dz. cyt., s. 107-117; tenże, Handlungskompetenzen des Religionslehrers und Katecheten..., s. 141-156.

27 Por. DOK 219.

28 Por. PDK 13

29 Por. A. Kiciński, Przygotowanie do sakramentów inicjacji chrześcijańskiej, „Ateneum Kapłańskie” 143 (2004) z. 2 (573), s. 227, 235.

30 CT 23.

31 PDK 25. 
Chrystusem obecnym w sakramentach, ale do podtrzymywania stałej relacji, opartej na uczestnictwie w sakramentach, modlitwie i liturgii.

Pogłębiona analiza posługi katechetycznej prowadzonej przez Kościoły partykularne w Polsce prowadzi do konkluzji, iż nadal występują pilne zadania, które wymagają natychmiastowego i zintensyfikowanego podjęcia. Niewątpliwie należy do nich wychowywanie do życia wspólnotowego i umiłowania Kościoła oraz do życia w malżeństwie i rodzinie. Dodatkowo obecnie następuje zwiększenie czynników laicyzacyjnych, wpływających szczególnie na młode pokolenie Polaków, co przy jednoczesnej akceleracji dojrzewania fizycznego i psychicznego młodzieży intensyfikuje procesy odrzucania identyfikacji z Kościołem, to zaś jest szczególnie zauważalne w tych Kościołach partykularnych w Polsce, w których występuje duża migracja zarobkowa. Powracający z wyjazdów zarobkowych młodzi ludzie przekazują swoim koleżankom i kolegom nowe style życia i odmienną od tradycyjnej hierarchię wartości.

Niestety, zagadnienie nowych czynników zaburzających prawidłowy rozwój religijny polskiej młodzieży nie jest zwykle podejmowane w katechezie przygotowującej do sakramentu bierzmowania. Zazwyczaj kandydaci do bierzmowania otrzymują katechizm zawierający podstawowe prawdy wiary, które ponownie poznają i memoryzują. Jednak tak ograniczone działanie w małym stopniu wpływa na katechizowanych. Katechizowany potrzebuje wspólnoty, by doświadczyć misterium Kościoła, a jednocześnie odkrywać rolę całej wspólnoty osób ${ }^{32}$. Katecheza młodzieży ${ }^{33}$ zakłada wdrażanie katechizowanych zarówno w zasady życia wspólnoty parafialnej, jak i procesy konstytuujące wspólnotę rodzinną.

Biorąc pod uwagę zróżnicowanie parafian ze względu na wiek, płeć, pochodzenie społeczne, wykształcenie, wykonywany zawód, a przede wszystkim poziom religijności, potrzeba wdrażania wielu adekwatnych form katechezy parafialnej w zależności od rozpoznanych potrzeb. Poprawna diagnoza sytuacji katechetyczno-pastoralnej danej parafii umożliwi poszukiwanie nowych form katechezy ${ }^{34}$. Przy czym zarówno dla pełnego rozwoju wiary wszystkich członków Kościoła, jak i dla przyszłości Kościoła bardzo duże znaczenie

32 Por. FC 17.

33 Por. DOK 185.

10434 Por. J. O’Shea, V. Cosstick, D. Lundy, Parish Project, dz. cyt., s. 16-29. 
ma katecheza permanentna. Ze względu na osłabienie lub nawet zniszczenie wielu środowisk przekazu wiary w XXI wieku, wiedza religijna, wartości chrześcijańskie, normy, rytuały, tradycje nie są już przekazywane razem z kulturą, jak to miało miejsce w społeczeństwach tradycyjnych. W społeczeństwie ponowoczesnym taką funkcję mogą spełniać tylko ściśle religijne środowiska, stąd niezbędność rozwoju i formowania katechezy dorosłych w środowisku parafialnym. Prawidłowo realizowana katecheza dorosłych sprzyja podejmowaniu przez nich katechezy w rodzinie. Trudno oczekiwać realizacji przez rodziców wychowania do wiary w środowisku rodzinnym, jeśli nie są podejmowane w parafii adekwatne formy katechezy rodziców.

W teorii pastoralnej parafia powinna być podstawową strukturą chrześcijańską, jednostką pastoralną Kościoła partykularnego oraz owocnym środowiskiem życia chrześcijańskiego. Jednak wspólcześnie parafia niejednokrotnie przestaje być wspólnotą, a staje się głównie ,punktem” udzielania sakramentów i sprawowania liturgii. W takiej sytuacji w parafii potrzeba inicjowania różnego typu wspólnot, które byłyby środowiskiem wzrostu chrześcijańskiego ludzi dorosłych. Przekonania, postawy, system wartości oraz wzory zachowań są w dużej mierze formowane przez wspólnotę wierzących, dlatego dorosły potrzebuje chrześcijańskiego otoczenia, by uzyskać wsparcie w procesie rozwoju osobowego i religijnego ${ }^{35}$. Przed chrztem dziecka winna być prowadzona katecheza rodziców oraz rodziców chrzestnych z zachowaniem jej wielowymiarowego charakteru: przypomnienie prawd wiary zawiązanych z pierwszym sakramentem, wyjaśnienie stosowanej podczas chrztu symboliki, przygotowanie liturgiczne. Cenne bylyby także wskazania dotyczące wychowania małego dziecka do wiary. Ze względu na zwiększającą się dysproporcję między uzyskiwanym współcześnie wykształceniem zawodowym a wykształceniem teologicznym warto zadbać o zaproponowanie odpowiedniej literatury pedagogiczno-katechetycznej, filmów rodzinnych, materiałów internetowych, co wymaga usuwania powstałego stereotypu, że formacja religijna rodziców kończy się po przyjęciu przez dziecko I komunii

35 Por. R. Kamiński, Funkcje tradycyjne i nowe parafii terytorialnej, „, Roczniki Teologiczno-Kanoniczne” 32 (1985) z. 6, s. 63; F. Woronowski, Organizowanie parafii nowoczesnej, Łomża 1993. 
świętej. Ewangelizacja i katecheza dorosłych wymaga tworzenia małych wspólnot, w których mogliby przedstawiać swoje wątpliwości, pytania, trudności dotyczące zarówno kwestii teologicznych, jak i pedagogiczno-katechetycznych ${ }^{36}$. Aktualnie coraz większe trudności rodzi zamykanie się człowieka w przestrzeni wirtualnej, przy jednoczesnej izolacji społecznej, co niekiedy skłania wspólczesnych dorosłych do poszukiwania wirtualnej parafii lub wirtualnego duszpasterza. Przynosi to ogromne wyzwanie dla wspólczesnej katechezy, by potrafila zmotywować katechizowanych do przejścia z „cyberprzestrzeni” do realnej wspólnoty katechetycznej. Najlepsze spotkania online nie zastąpią spotkania człowieka z Jezusem Chrystusem na modlitwie i w sakramentach, a szczególnie w Eucharystii ${ }^{37}$.

Warto pamiętać także o rekolekcjach parafialnych, misjach, działalności katechetycznej grup i ruchów religijnych, wychowawczych, młodzieżowych. Katecheza realizowana w ramach stowarzyszeń ujmuje te grupy jako wspólnoty ściśle związane z parafią ${ }^{38}$, które w dużym stopniu umożliwiają dzieciom i młodzieży wspólne poszukiwania. Poprzez katechezę parafialną należy podjąć działania z grupami specjalistycznymi i zawodowymi, np. rolników, nauczycieli, pracowników samorządu lokalnego. Osoby należące do zbliżonych grup zawodowych posiadają podobne kwalifikacje zawodowe, poziom intelektualny, zbliżony zakres doświadczeń życiowych i zawodowych, przeżywają podobne trudności i problemy związane z pracą ${ }^{39}$. Formacja osobowa i religijna dorosłych zaangażowanych zawodowo podejmowana w ramach katechezy wymaga działania na trzech płaszczyznach wzajemnie się uzupełniających. Najpierw niezbędne jest kształtowanie świadomości chrześcijańskiej, następnie potrzebne są działania skierowane na rozwój życia chrześcijańskiego (praktyki religijne, indywidualna praca nad sobą,

36 Por. W. Piwowarski, Problemy duszpasterskie parafii terytorialnych, „Roczniki Teologiczno-Kanoniczne" 32 (1985) z. 6, s. 72-74.

37 Por. G. Grochowski, Kościót na temat katechetycznego wykorzystania Internetu, „Katecheta” 47 (2003) nr 2, s. 10-18; E. Osewska, Modele komunikacji interpersonalnej $i$ ich znaczenie dla katechezy, [w:] Wybrane zagadnienia z katechetyki, red. J. Stala, Tarnów 2003, s. 111-142.

38 Por. DOK 262.

39 Por. R. Kamiński, Parafia miejscem realizacji duszpasterstwa, [w:] Teologia pastoralna, t. 2: Teologia pastoralna szczegótowa, red. R. Kamiński, Lublin 2002, s. 66. 
formacja liturgiczno-modlitewna, służba na rzecz bliźniego) oraz budowanie wspólnoty (nawiązywanie przyjaźni, odnajdywanie swego miejsca w Kościele ${ }^{40}$.

Zgodnie z Katechizmem Kościoła katolickiego [dalej: KKK] „Kościół Chrystusowy jest prawdziwie obecny we wszystkich prawowitych miejscowych zrzeszeniach wiernych, które trwając przy swoich pasterzach, same również nazywane są Kościołami w Nowym Testamencie [...]. W nich głoszenie Ewangelii Chrystusowej zgromadza wiernych i w nich sprawowana jest tajemnica Wieczerzy Pańskiej [...]. W tych wspólnotach, choć nieraz są one szczupłe i ubogie albo żyją w rozproszeniu, obecny jest Chrystus, którego mocą zgromadza się jeden, święty, katolicki i apostolski Kościól”"11. Kościól partykularny, pozostając w łączności z Kościołem powszechnym, podejmuje i realizuje wszystkie cele i zadania, wśród których należy wymienić również katechizację. Szczególną odpowiedzialność za głoszenie słowa Bożego i formację wiernych ponoszą biskupi jako pierwsi katecheci Kościoła partykularnego ${ }^{42}$. Bardzo szczegółowo działania biskupa przedstawiające jego troskę o katechezę zostały opisane w Dyrektorium katechetycznym Kościola katolickiego w Polsce ${ }^{43}$ : katecheza skierowana do wiernych diecezji, troska o fundusze przeznaczone na katechezę, troska o przygotowanie adekwatnych pomocy katechetycznych, czuwanie nad autentycznością i prawowiernością przekazywanych prawd wiary, motywowanie wiernych do działań katechetycznych, dbanie o kompetentnych nauczycieli religii i katechetów, koordynacja działań katechetycznych podejmowanych w diecezji, w tym przygotowanie spójnego programu katechetycznego włączonego w plan duszpasterski i zgodnego z planami Konferencji Episkopatu Polski.

Skuteczność katechezy zależy od bardzo wielu czynników i uwarunkowań, jednak u jej podstaw znajduje się zawsze osoba mądrego i odpowiedzialnego katechety - rozpoczynając od pierwszego

40 Por. M. Zając, Katecheza parafialna, [w:] Wybrane zagadnienia z katechetyki, dz. cyt., s. 195-233.

41 KKK 832.

42 Por. KKK 833

43 Por. PDK 124; DOK 223; CT 63; KPK, kan. 775 \ 1. 
katechety Kościoła partykularnego - biskupa, poprzez rodziców, kapłanów, katechetów parafialnych, nauczycieli religii aż po wszystkich wierzących. Mądre, odpowiedzialne i solidarne działanie wszystkich członków Kościoła partykularnego pozostających w żywym związku z Jezusem Chrystusem ustawicznie wzmacnia i buduje katechezę, czyniąc ją coraz bardziej owocną.

Elżbieta Osewska, Postuga katechetyczna Kościoła partykularnego, [w:] Kościót lokalny w Kościele Chrystusa, red. ks. Robert Kantor, Kraków 2015, s. 94-108 (Lumen Gentium, 1).

DOI: http://dx.doi.org/10.15633/9788374384810.06 